\title{
Genetic analysis of callus formation in a diversity panel of 96 rose genotypes
}

\author{
Thi Hong Nhung Nguyen ${ }^{1,3} \cdot$ Traud Winkelmann $^{2}$ (D) Thomas Debener $^{1}[$
}

Received: 1 April 2020 / Revised: 22 June 2020 / Accepted: 25 June 2020 / Published online: 7 July 2020

(c) The Author(s) 2020

\begin{abstract}
In a diversity panel of 96 rose genotypes, variation in the capacity to form calluses on leaf explants in vitro was investigated, and a genome-wide association study (GWAS) was performed to identify genetic factors associated with callus formation. Calluses were induced from wounded in vitro leaflets on two media differing in their plant growth regulator composition. Significant differences between genotypes were observed in callus size on the first callus-inducing medium (CIM1, containing $10.7 \mu \mathrm{M}$ naphthylene acetic acid) using a $0-4$ scale, as well as on a second callus-inducing medium (CIM2, containing $4.5 \mu \mathrm{M}$ dichlorophenoxyacetic acid and $2 \mu \mathrm{M}$ 6-( $\gamma, \gamma$-dimethylallylaminopurine $)$ ) with callus size scales of $0.82-4$. GWAS utilizing the WagRhSNP 68K SNP array for callus size induced on either CIM1 or CIM2 enabled the identification of 26 and 13 significantly associated SNPs, respectively. Among these SNPs, we found the SNPs Rh12GR_12098_1092Q (uncharacterized gene) and RhMCRND_2903_1233Q in a gene encoding a pentatricopeptide repeat-containing protein were associated with callus size on CIM1, with large effects being observed between alleles. Two SNPs, RhK5_5473_763P ( $S$-formylglutathione hydrolase) and Rh12GR_37799_568Q (polyglutamine binding protein, WW domain binding protein), were associated with callus size on CIM2 with large effect sizes. The markers associated with callus size on CIM1 form a large cluster on chromosome 3 and minor clusters on other chromosomes and provide the first preliminary indications of candidate genes responsible for the observed phenotypic variation.
\end{abstract}

\section{Key message}

Callus formation in rose is strongly genotype dependent and varies continuously among 96 genotypes. A major QTL associated to callus size was located on chromosome 3 .

Keywords Rosa $x$ hybrida $\cdot$ Callus induction · SNP markers · Genome-wide association study (GWAS)

\section{Introduction}

Editorial Responsibility: Ming-Tsair Chan.

Electronic supplementary material The online version of this article (https://doi.org/10.1007/s11240-020-01875-6) contains supplementary material, which is available to authorized users.

Thomas Debener

debener@genetik.uni-hannover.de

1 Institute of Plant Genetics, Molecular Plant Breeding Unit, Leibniz Universität Hannover, Hannover, Germany

2 Section Woody Plant and Propagation Physiology, Institute of Horticultural Production Systems, Leibniz Universität Hannover, Hannover, Germany

3 Institute of Agricultural Genetics, Institute of Vietnam Academy of Agriculture Science, Hanoi, Vietnam
Roses are among the most popular and economically important horticultural crops. These plants are used for many different purposes, such as ornamental plants as cut flowers, potted plants and garden plants, as well as for the food, pharmaceutical and perfume industries (Leus et al. 2018). Currently, there are approximately 30,000-35,000 known cultivated rose varieties, most of which are tetraploids of complex interspecific hybrid origin, are highly heterozygous and cover a wide phenotypic variability (Bendahmane et al. 2013; Kirov et al. 2014). However, roses propagated by seeds will not fall true-to-type, vegetative propagation by cuttings, layering, budding and grafting may be timeconsuming, and there may be a limitation in stock plants (Marchant et al. 1996). In vitro propagation of roses allows 
rapid multiplication, the production of disease-free plants and the application of genetic engineering to test gene functions and accelerate breeding programs. However, the high input of labor and strong genotypic differences in propagation and rooting efficiency make the in vitro propagation of roses economically infeasible for most genotypes.

When conducting genetic engineering, in vitro regeneration is a prerequisite, and regeneration via organogenesis and somatic embryogenesis often involves the induction of calluses, e.g., undifferentiated and proliferating cells, as the first step. Furthermore, callus formation is important to seal wounds, prevent water loss and provide cellular sources for vasculature differentiation (Ikeuchi et al. 2017). Incubating various types of explants on auxin-rich callus-inducing media (CIM) can induce callus formation (Dale and Deambrogio 1979; Ikeuchi et al. 2013; Bello et al. 2018; Shin and Seo 2018). Callus induction occurs when plant cells dedifferentiate and proliferate. This process is controlled by many factors, particularly the interplay of the plant hormones auxin and cytokinin, and it requires the expression of developmental genetic factors, such as PASTICCINO (PAS) genes, for coordinating cell division and differentiation of plant cells during development (Harrar et al. 2003). A rapidly transmitted wound signal activates jasmonic acid (JA) and its biologically active derivatives, which regulate a wide range of biological processes, including plant defense, secondary metabolism and growth (Koo et al. 2009). During callus development, many upregulated genes are involved in the response to stress, and callus development displays histological features similar to the root meristem, which is controlled by the spatial expression of root meristem regulator genes, such as WOX5 and SHORT ROOT (Sugimoto et al. 2010). Similar to root formation, callus formation was shown to be activated by the expression of transcription factors, such as LATERAL ORGAN BOUNDARIES DOMAIN (LBD)16, LBD17, LBD18, and LBD29 (Fan et al. 2012; Kareem et al. 2015; Okushima et al. 2007). The ARABIDOPSIS TRITHORAXRELATED 2 (ATXR2) was employed to $L B D$ promoters by the transcription factors $A U X I N$ RESPONSE FACTOR 7 (ARF7) and ARF19 and regulated callus formation (Lee et al. 2017). Another factor influencing callus formation is the gene ENHANCER OF SHOOT REGENERATION1, which was shown to be directly upregulated by WOUND INDUCED DEDIFFERENTIATIONI, an Apetala 2/ethylene response factor transcription factor (AP2/ERF) in Arabidopsis thaliana that stimulates callus formation and shoot regeneration (Che et al. 2006; Iwase et al. 2011, 2017). The reactivation of core cell cycle regulators, such as CYCLIN (CYC) and CYCLIN-DEPENDENT KINASES (CDK), leads to callus formation and organ regeneration. (Cheng et al. 2015; Inzé and Veylder 2006). Furthermore, very-long-chain fatty acid synthesis is catalyzed by the enzyme 3-KETOACYL-COA SYNTHASE 1 (KCS1), whose mutation enhances callus formation from pericycle cells (Shang et al. 2016), and the genes ETHYLENE RESPONSE FACTOR 115, PLETHORA3, PLETHORA5 and PLETHORA7 have been recently identified as factors involved in callus generation (Sena et al. 2009; Xu et al. 2018). Although these physiological and molecular studies identified genes with effects on callus induction in recent years, the molecular mechanisms and the integration of environmental and endogenous signals are highly complex and have not been fully elucidated to date.

Several studies on callus induction in roses have been performed, mostly for developing transformation and/or regeneration protocols (Canli 2003; Hsia and Korban 1996; Huang et al. 2018; Khosh-Khui and Sink 1982; Kuusiene and Kandzezauskaite 2001; Noriega and Söndahl 1991; Pati et al. 2010; Zakizadeh et al. 2010). However, neither the genetic complexity of callus formation of roses nor the genes involved in these processes have been studied to date. In recent years, genome-wide association studies (GWASs) have been found to be an effective strategy for discovering underlying complex genetic traits (Chen et al. 2017). In roses, GWAS has been used to determine the loci associated with anthocyanin and carotenoid concentrations in petals (Schulz et al. 2016) with adventitious shoot and root regeneration (Nguyen et al. 2017, 2020) and petal numbers (Hibrand Saint-Oyant et al. 2018). These studies are the first examples for identifying quantitative trait loci (QTLs) via GWAS and the discovery of genes and markers for complex traits of roses.

In this study, we investigated the capacity for callus induction of 96 rose genotypes in a diversity panel previously analyzed for other traits (Nguyen et al. 2017; Schulz et al. 2016). Based on SNPs from the Axiom WagRhSNP array (Koning-Boucoiran et al. 2015), the variation in callus induction of 96 rose genotypes was analyzed using GWAS. The aim of this study was to identify SNP markers and chromosome (ChR) regions, as well as candidate genes, associated with the callus formation ability of rose.

\section{Materials and methods}

\section{Plant material and in vitro establishment}

The nodal stem segments of 96 rose genotypes (Supplementary Table S1) close to the apical meristem were collected from healthy plants in the greenhouse of the Federal Plant Variety Office in Hannover, Germany. The population was chosen because other traits had been analyzed previously and all plants had already been genotyped with an SNP array (Nguyen et al. 2017; Schulz et al. 2016). The stem segments were surface disinfected for $1 \mathrm{~min}$ in $70 \%$ ethanol, then for $10 \mathrm{~min}$ in $1 \%$ sodium hypochlorite solution and 
finally rinsed 4 times in sterile deionized water. The culture medium for shoot proliferation consisted of MS (Murashige and Skoog 1962) basal salts with ferric ethylenediamine di2-hydroxylphenyl acetate (instead of ferric ethylenediamine tetraacetic acid), $30 \mathrm{~g} \mathrm{~L}^{-1}$ sucrose, $8 \mathrm{~g} \mathrm{~L}^{-1}$ plant agar, 2.22 $\mu \mathrm{M}$ BAP (benzylaminopurine) and $0.58 \mu \mathrm{M} \mathrm{GA}_{3}$ (gibberellic acid) (Duchefa, Harlem, Netherlands) as described in Nguyen et al. (2017). After two weeks, the shoots emerging from the axillary buds were excised and transferred to fresh medium to promote shoot growth and proliferation.

\section{Callus induction}

Leaves of the upper part of vigorously growing in vitro shoots were used to prepare explants for callus induction. The petioles of single leaflets were removed, and three incisions were incised on the abaxial surface of the leaflet. All leaflet explants were placed with the adaxial surface in contact with the medium. Two media, CIM1 and CIM2 (Table 1), that had been used previously to induce embryogenic calluses in roses and cyclamen (Dohm et al. 2001; Prange et al. 2010), were compared.

For each rose genotype, ten leaflet explants were cultured in Petri dishes with $94 \mathrm{~mm}$ diameter with five replicates each, and the experiment was repeated three times. The explants were incubated in darkness for four weeks at $24 \pm$ $2{ }^{\circ} \mathrm{C}$. Callus development was scored based on the proportion of callus covering the leaflet using a $0-4$ scale (Fig. 1), where 0 indicated no callus formation, 1 indicated less than $25 \%$ of the leaflet covered by callus, 2 represented $2-50 \%$ coverage, 3 indicated $51-75 \%$ coverage, and 4 signified more than $75 \%$ of the leaflet being covered by callus (Tuskan et al.
2018). The average callus size per experiment was calculated as.

Callus size $=\mathrm{n} \times \mathrm{G} / \mathrm{N}$ with $\mathrm{n}$ as the number of explants forming callus, $\mathrm{G}$ as the scale of callus rating for each explant and $\mathrm{N}$ being the total number of explants.

\section{Statistical analyses}

Data were analyzed for differences between genotypes and repetitions of the experiments with the Kruskal-Wallis test. Normal distribution of the traits was tested using a quasibinomial model. The correlation coefficient between callus traits was calculated with Pearson's rank correlation. All statistical analyses were performed with the R software package, version 3.2.5 (The R-foundation for statistical computing 2016).

\section{Association mapping}

SNPs were analyzed with the Axiom WagRhSNP 68K chip, which comprises 68,893 SNPs (scored on both DNA strands independently) derived from cut and garden roses (KoningBoucoiran et al. 2015). The SNP dosage was estimated for each of the five allelic classes by fit Tetra (AAAA, AAAB, AABB, ABBB and BBBB) (Voorrips et al. 2011).

The association analysis was performed in TASSEL, version 3.0 (Bradbury et al. 2007) using information from the 96 genotypes for callus induction and genotypic data comprising 68,893 SNPs. To investigate associations between SNPs and callus formation traits, a linear mixed model was used with a minor allele frequency of 0.05 . The $\mathrm{Q}$ matrix was obtained using STRUCTURE, version 2.3 (Hubisz et al. 2009) based on a subset of markers. The K matrix was
Table 1 Composition of callus induction media CIM1 and CIM2

\begin{tabular}{lllll}
\hline Media & Salts and vitamins & $\begin{array}{l}\text { Plant growth } \\
\text { regulators } \\
(\mu \mathrm{M})\end{array}$ & Carbon source & Solidifying agent \\
\hline CIM1 & Full-strength MS basal salts and vitamins & NAA (10.7) & $30 \mathrm{~g} \mathrm{~L}^{-1}$ glucose & $4.0 \mathrm{~g} \mathrm{~L}^{-1}$ Gelrite \\
CIM2 & Full-strength MS basal salts and vitamins & $\begin{array}{l}2.4 \mathrm{D}(4.5) \\
2 \mathrm{iP}(2)\end{array}$ & $30 \mathrm{~g} \mathrm{~L}^{-1}$ glucose & $4.0 \mathrm{~g} \mathrm{~L}^{-1}$ Gelrite \\
\hline
\end{tabular}
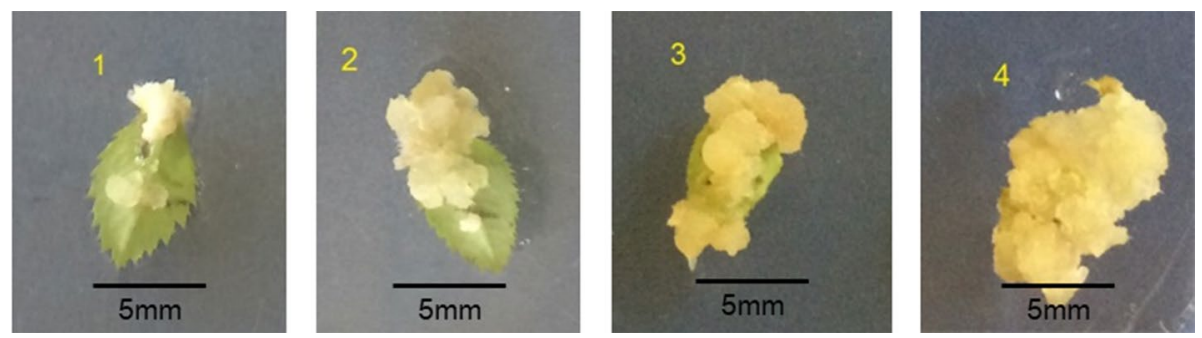

Fig. 1 Example of the rating of callus size with relative visual scores between 0 and 4 . The rating of callus size is given by the numbers at the top of each picture with 1 indicating less than $25 \% ; 2=26-50 \% ; 3=51-75 \%$; and 4 more than $75 \%$ of the leaflet being covered by callus 
calculated with SPAGeDi 1.3 software (Hardy and Vekemans 2002). Association analyses were performed for each trait. The significance between traits and markers in the association was defined with the Bonferroni method using a threshold set to $-\log$ p $10>6.7(<3.3 \mathrm{E}-06)$. The allelic class effects were obtained directly from the TASSEL output.

To visualize the associations, significant SNPs were used to blast against the Rosa chinensis 'Old Blush' genome (Hibrand Saint-Oyant et al. 2018) for localized SNP searching in the rose ChR from Bio Edit (Hall 1999). A homology search via a BLAST analysis on https://blast.ncbi.nlm.nih. gov/Blast.cgi was performed to locate the genes associated with the traits.

\section{Results}

\section{Callus formation}

Callus formation started from the edges of wounds of the leaflet explants and gradually grew to completely cover the explants after 28 days in the case of some genotypes
(Fig. 1, Fig. S1). The amount of callus, expressed on a callus scale of 0 to 4 , varied considerably among genotypes (Supplementary Table S1, Fig. S1). On CIM1, 95 of 96 genotypes showed callus formation, with only leaflets of the cultivar Jazz failing to form callus (Fig. 2a). On CIM2, leaflets of all genotypes formed calluses, with callus sizes ranging from 0.8 to 4 (Fig. 2b). Overall, the sizes were higher than those recorded on CIM1. Interestingly, on both media, the lowest callus size was observed for the same group of genotypes, including Jazz, Ausfather, Blue Perfume, Perennial Blush, Comtessa Al, Feuerwerk, Magenta and Herkules (Fig. 2). Statistical analysis of the data for callus induction on both CIM1 and CIM2 revealed significant differences between genotypes at $p=0.05$ using a Kruskal-Wallis test, whereas no significant differences were revealed between the repeat experiments (Tukey's test). In addition to callus formation, other in vitro regeneration traits that had been analyzed in previous studies (Nguyen et al. 2017, 2020) were used to analyze pairwise correlations (Table 2). A high correlation was found between callus size on CIM1 and CIM2 (0.76), whereas weaker but highly significant correlations were observed between the shoot propagation rate and callus size (CIM1:
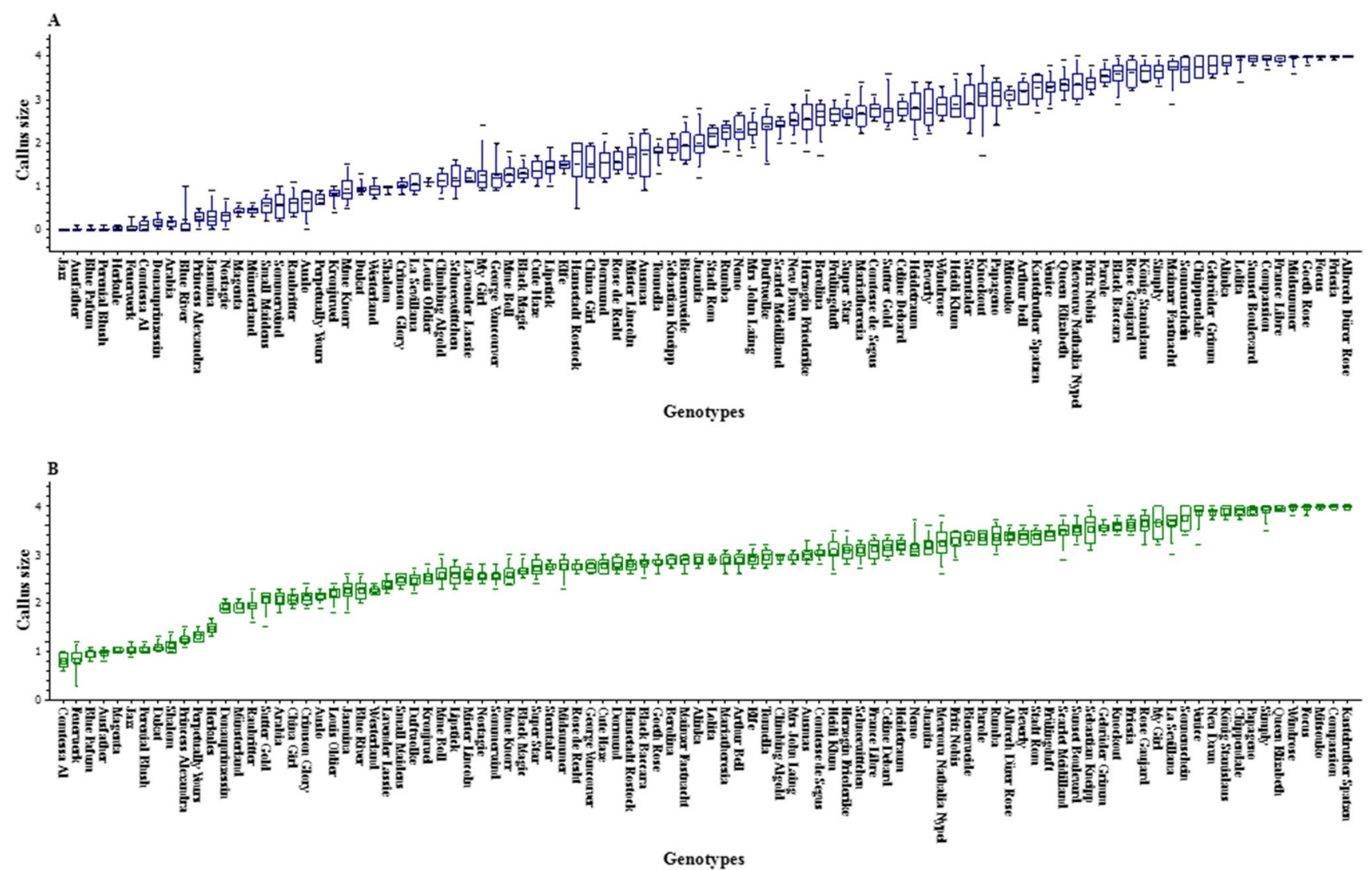

Fig. 2 Average callus size of the 96 rose genotypes after four weeks of culture on CIM1 (a) and CIM2 (b) based on three independent experiments using five biological replicates (with ten explants each).
Small square $=$ mean; horizontal lines $=$ median; minimum, maximum; box $=1$ st and 3rd quartiles; and whisker $=$ standard deviation 
Table 2 Pearson's correlation coefficients for different in vitro traits of 96 rose genotypes (from the present and previous studies) and the corresponding $\mathrm{p}$-values (in italics)

\begin{tabular}{|c|c|c|c|c|c|}
\hline Pearson's correlation coefficient & Callus induction CIM2 & $\begin{array}{l}\text { Axillary shoot } \\
\text { proliferation }\end{array}$ & $\begin{array}{l}\text { Adventitious shoot } \\
\text { regeneration }\end{array}$ & Root number ${ }^{b}$ & Root length $^{\mathrm{b}}$ \\
\hline \multirow[t]{2}{*}{ Callus induction CIM1 } & 0.76 & 0.54 & 0.29 & 0.37 & 0.21 \\
\hline & $<2.2 * 10^{-16}$ & $1.50 * 10^{-8}$ & 0.005 & $1.83 * 10^{-3}$ & 0.039 \\
\hline \multirow[t]{2}{*}{ Callus induction CIM2 } & & 0.63 & 0.26 & 0.43 & 0.27 \\
\hline & & $7.60 * 10^{-12}$ & 0.010 & $1.24 * 10^{-5}$ & 0.007 \\
\hline \multirow[t]{2}{*}{ Axillary shoot proliferation ${ }^{\mathrm{c}}$} & & & 0.06 & 0.59 & 0.34 \\
\hline & & & 0.56 & $4.45 * 10^{-10}$ & $6.68 * 10^{-3}$ \\
\hline \multirow[t]{2}{*}{ Adventitious shoot regeneration $^{\mathrm{a}}$} & & & & 0.04 & 0.00 \\
\hline & & & & 0.68 & 0.98 \\
\hline \multirow[t]{2}{*}{ Root number ${ }^{b}$} & & & & & 0.70 \\
\hline & & & & & $1.85 * 10^{-15}$ \\
\hline
\end{tabular}

Significant correlations are given in bold

${ }^{a}$ Data published by Nguyen et al. (2017)

${ }^{\mathrm{b}}$ Data published by Nguyen et al. (2020)

${ }^{\mathrm{c}}$ Unpublished data

0.54 and CIM2: 0.63 ) and with adventitious shoot regeneration and in vitro rooting traits (Table 2).

\section{Marker-trait association analysis}

GWAS was performed with the data for the average callus size of the 96 rose genotypes to identify and localize genetic factors associated with this trait. For callus induction on CIM1, 21 SNPs significantly associated with callus size were found (Table 3; Fig. 3a). Almost all SPNs colocalized on ChR 03 and formed one large conspicuous cluster, indicating a major effect QTL at this position in the rose genome. Only three significant SNPs were found on ChR 00, forming a second cluster. Some SNPs had large effects, such as Rh12GR_12098_1092Q at position 370111 on ChR 03, Rh12GR_6077_815P at position 5193454, Rh12GR_86832_276 and RhMCRND_2903_1233Q at position 25447590 on ChR 03 (Table 3; Fig. 4). Apart from the significant $p$-value, these markers also display a dose-dependent effect of the alternative alleles (Fig. 4), further supporting the significance of the association between markers and traits.

GWAS analyses of the callus size on CIM2 revealed 11 significantly associated SNPs (Table 4; Fig. 3b). Among these SNPs, three were located on ChR02, six were on ChR03, one was on ChR04 and two were on ChR06. Some SNPs showed large effect sizes, such as Rh12GR_37799_568Q (NA) at position 6468674 on ChR 03 and RhK5_5473_763Q and RhK5_5473_763 at position 18402920 on ChR 03 (Table 4; Fig. 5). Of all the SNPs associated with callus size, only 2 SNPs overlapped between CIM1 and CIM2. These SNPs were RhK5_4750_1179Q and Rh12RG_37799_568Q (Tables 3 and 4).

\section{Discussion}

In this study, we present data on callus formation in an association panel comprising 96 rose genotypes on two in vitro media and its correlation to other traits related to developmental processes. Furthermore, we identified genomic regions associated with callus formation and located a selection of candidate genes possessing known functions for callus induction in relation to these regions.

\section{Callus induction in a panel of 96 rose genotypes}

Callus induction is the first step for plant regeneration via somatic embryogenesis or via organogenesis for many plants, such as potato (Kumlay and Ercisli 2015) oil palm (Jayanthi et al. 2015; Yunista and Hapsoro 2011), bamboo (Yuan et al. 2013), Lycium barbarum (Osman et al. 2013), Jatropha curcas (Shamsiah et al. 2011), soybean (Yang et al. 2011), wheat (Ma et al. 2016) and hawthorn (Taimori et al. 2016). For roses, callus induction using leaf and stem explants was established first with Rosa manetti Hort. and R. hybrida L.cv. Tropicana (Khosh-Khui and Sink 1982). A range of different rose genotypes and plant hormones were used for callus induction. The callus of two cultivars, 'Heckenzauber' and 'Pariser Charme', was induced on CIM1 and gave rise to embryogenic cultures (Dohm et al. 2001). Our 


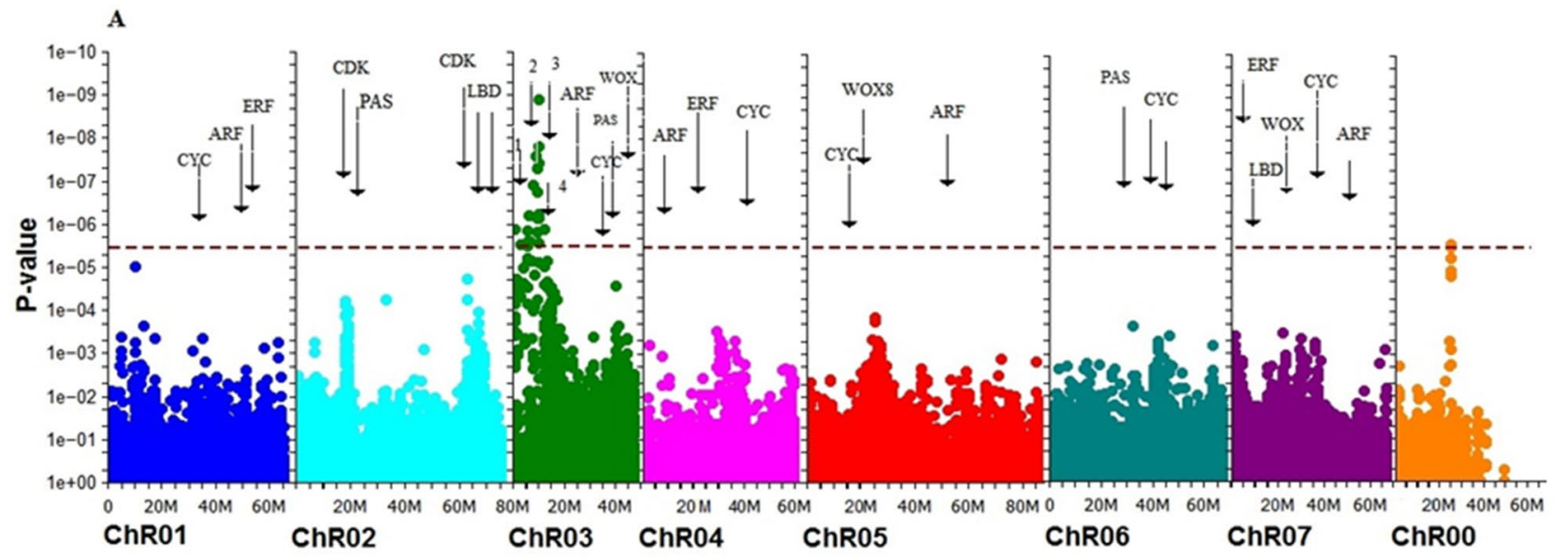

B
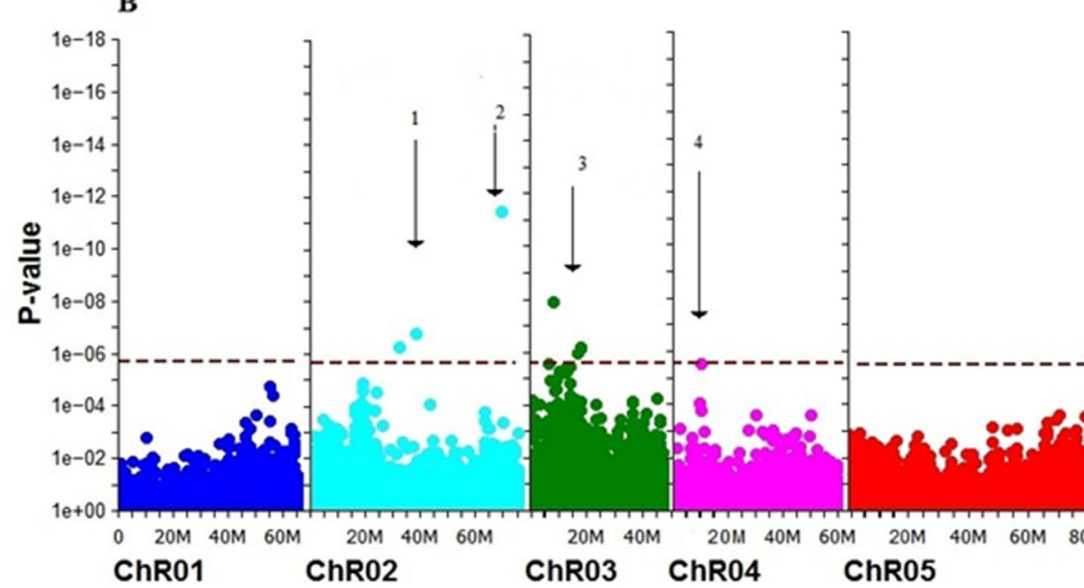
ChR01 ChR02 ChR03 ChR04 ChR05

$60 \mathrm{M} 80 \mathrm{M}$

Fig. 3 Manhattan plot of callus size induced on CIM1 (A) and CIM2 (B) The red dashed line represents the Bonferroni threshold of the adjusted significance level $-[\log 10]=6.7$ The subdivision of the $\mathrm{x}$-axis is by chromosome (ChR01-ChR00), including chromosome 00 with contigs not assigned to a precise location to date. Each scale bar of the x-axis represents $5 \mathrm{Mb}$. Note: A 1: Rosa chinensis spliceosome-associated protein 130 A, 2: Rosa chinensis protein C2-DOMAIN ABA-RELATED 5-like (LOC112192906), mRNA, 3: Rosa chinensis glutathione S-transferase DHAR3, chloroplastic (LOC112195020), mRNA, 4: Rosa chinensis putative pentatricopeptide repeat-containing protein At5g08490 (LOC112193021), transcript variant $\mathrm{X} 2$. Candidate genes: $A R F$ auxin response factor, $C Y C$ cyclin, $C D K$ cyclin dependent kinase, ERF ethylene-

comprehensive data set enables a detailed comparison of callus formation in two different media among 96 genotypes, the largest number of rose genotypes in a single study on callus formation published to date. Our data indicated that on CIM2, explants of rose genotypes on average formed more calluses than on CIM1, but the genotypes with a small average callus size were similar on both media. This observation and a high correlation of callus formation between the two media (Table 2) suggested that they were controlled at least in part by the same genetic factors. This finding is expected, as both media used auxin as the major growth regulator responsive transcription factor, $L B D$ LATERAL ORGAN BOUNDARIES, PAS PASTICCINO, WOX: WUSCHEL-related homeobox. B 1: Rosa chinensis transmembrane E3 ubiquitin-protein ligase 1 (LOC112188470), transcript variant X1, mRNA, 2: Rosa chinensis uncharacterized CRM domain-containing protein At3g25440, chloroplastic (LOC112193599), transcript variant X1, mRNA, 3: Rosa chinensis polyglutamine binding protein, WW domain binding protein, 4: Rosa chinensis protein SULFUR DEFICIENCY-INDUCED 2 (LOC112201022), mRNA, 5: Rosa chinensis chromatin modificationrelated protein EAF1 B-like (LOC112172241), transcript variant X2, mRNA, 6: Rosa chinensis 54S ribosomal protein L24, mitochondrial (LOC112174756), mRNA

and only differed in the type of auxin (NAA in CIM1 and 2,4-D in CIM2), as well as an additional cytokinin (2iP) in CIM2. Although we found a lower correlation between callus size and other in vitro traits, some of these correlations, such as axillary shoot proliferation, ranged between 0.54 and 0.63 for CIM1 and CIM2, respectively, and were highly significant (Table 2). It is tempting to speculate that common genetic factors play a role in both processes, and likely candidates might be found in the role of auxin perception and signaling, which are crucial for both callus formation and the outgrowth of side shoots in plants. This finding might 


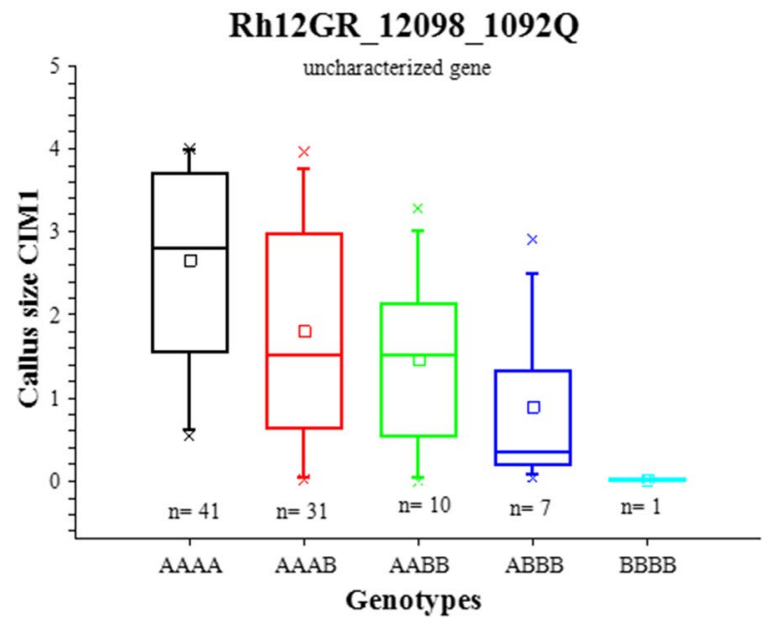

Fig. 4 Genotypic effects of SNP markers associated with callus size on CIM1, Rh12GR_12098_1092Q (Rosa chinensis uncharacterized LOC112192505) and RhMCRND_2903_1233Q (Rosa chinensis pentatricopeptide repeat-containing protein At5g15010,

also be observed for the somewhat weaker but still highly significant correlations of callus size to root numbers $(0.37$ and 0.43 ). Some authors have found that signaling networks between callus of Arabidopsis induced on callus-inducing media partially overlap with those leading to the formation of lateral root primordia, which might cause some of the correlations (Sugimoto et al. 2010; Fan et al. 2012; Ikeuchi et al. 2013). However, based on these data alone, causal relations cannot be inferred and need further functional analyses by, for example, overexpression or knockdown/knockout studies involving candidate genes identified for callus induction.

\section{Marker-trait association analysis}

Recently, marker-trait associations have been analyzed for callus induction in a number of plants, such as Popиlus trichocarpa (Tuskan et al. 2018), soybean (Yang et al. 2011), rice (Zhang et al. 2019) and maize (Ma et al. 2018). In the present study, we detected 21 SNPs associated with callus size after induction on CIM1 and 11 SNPs associated with callus size on CIM2. Apart from significant p-values of markers associated with a trait, the formation of a marker peak above markers constituting statistical background noise can be taken as an indication of genetic factors that influence the trait under investigation. Among the SNPs significantly associated with callus size, some deserve a more detailed discussion: the SNP Rh12GR_59735_1764Q is located in a gene encoding spliceosome-associated protein 130A. This gene belongs to alternative splicing factors that have roles in regulating gene expression during the development of multicellular organisms and are important for stress adaptation in plants (Staiger and Brown 2013). Moreover, the spliceosome-associated protein 130A plays an indispensable

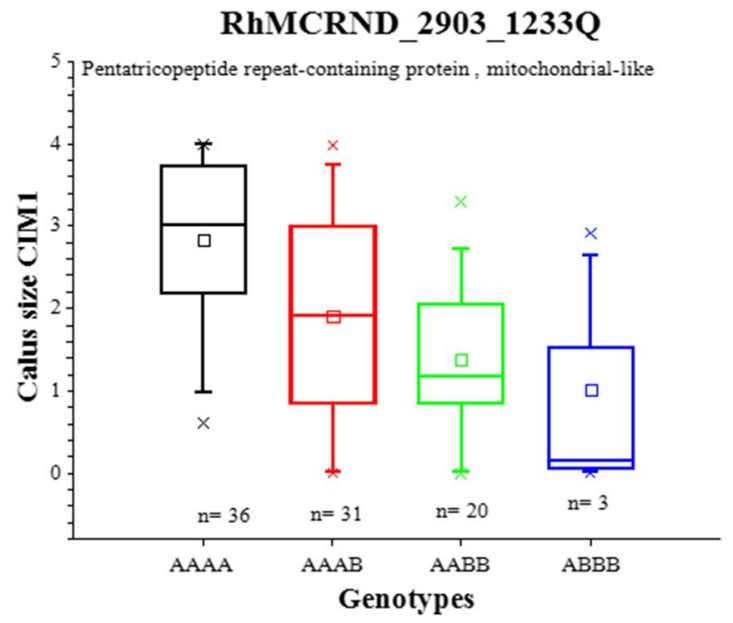

mitochondrial-like (LOC112192673)). Small square=mean; continuous line $=$ median; asterisk $=$ minimum, $\operatorname{maximum} ;$ box $=1$ st and 3rd quartiles; and whisker $=$ standard deviation)

role in the specific spatiotemporal events of reproduction (Aki et al. 2011). The SNPs Rh12GR_13539_496P and Rh12GR_13539_496Q are derived from genes encoding E3 ubiquitin-protein ligases similar to ARKADIA, which were found to be associated with the callus size induced on CIM1. RhK5_12450_841P lies in a gene encoding a Rosa chinensis transmembrane E3 ubiquitin-protein ligase 1 and is associated with the callus size induced on CIM2. These genes belong to the ubiquitination family and are involved in the regulation of cell cycle progression, transcriptional regulation, DNA repair, signal transduction and protein turnover (Ho et al. 2015; Pfeffer et al. 2015) and control organ size in a dosage-dependent manner in Arabidopsis (Disch et al. 2006).

For callus size on CIM2, we found an association with the SNP RhK5_107_2439P, which is located in a gene encoding a chromatin modification-related protein of the type EAF1 B-like (Fig. 3). This protein was identified in a stable subunit of $N u A 4$, a complex of a yeast histone $\mathrm{H} 4 / \mathrm{H} 2 \mathrm{~A}$ acetyltransferase implicated in DNA repair and gene regulation (Auger et al. 2008; Bieluszewski et al. 2015). The SNP RhK_5473_763P displays a strong effect between alleles associated with callus size on CIM2 (Fig. 5). This SNP is derived from a gene for S-formylglutathione hydrolase having a function in formaldehyde detoxification in animals and microorganisms, which was also found in Arabidopsis (Kordic et al. 2002). The $\mathrm{S}$-formylglutathione hydrolase was suggested to be involved in the detoxification of xenobiotics, such as herbicides (Gershater and Edwards 2007). It can be speculated that this enzyme might be involved in the metabolization of 2,4-D that was added to our medium CIM2. The gene for the 54S ribosomal protein L24, which harbors marker RhMCRND_10042_489P, was associated 
Table 3 Significant SNPs associated with callus size induced on CIM1

\begin{tabular}{|c|c|c|c|c|c|c|c|}
\hline \multirow[t]{2}{*}{ Marker } & \multirow[t]{2}{*}{ p-value } & \multicolumn{3}{|c|}{ Effects } & \multirow[t]{2}{*}{$\mathrm{ChR}$} & \multirow[t]{2}{*}{ Position } & \multirow[t]{2}{*}{ Gene } \\
\hline & & $\mathrm{A}: \mathrm{A}$ & $\mathrm{A}: \mathrm{B}$ & $\mathrm{B}: \mathrm{B}$ & & & \\
\hline Rh12GR_27683_2069P & $1.21 \mathrm{E}-09$ & - & 0 & 1.48 & 3 & 10166387 & $\begin{array}{l}\text { Rosa chinensis probable fructokinase-6, chloroplastic } \\
\text { (LOC112194730) }\end{array}$ \\
\hline Rh12GR_4846_920P & $2.62 \mathrm{E}-08$ & - & 0 & 1.36 & 3 & 8790885 & $\begin{array}{l}\text { Rosa chinensis DEAD-box ATP-dependent RNA helicase } 13 \\
\text { (LOC112193330) }\end{array}$ \\
\hline Rh12GR_59753_1764Q & $3.63 \mathrm{E}-08$ & - & 0 & 1.43 & NA & NA & Rosa chinensis TATA_element_modulatory_factor_(TMF) \\
\hline Rh12GR_25423_3834P & $4.84 \mathrm{E}-08$ & - & 1.30 & 0 & 3 & 9153717 & Rosa chinensis spliceosome-associated protein $130 \mathrm{~A}$ \\
\hline RhK5_4750_1179Q & $1.20 \mathrm{E}-07$ & 1.58 & 0 & - & 3 & 7868346 & $\begin{array}{l}\text { Rosa chinensis uncharacterized CRM domain-containing pro- } \\
\text { tein At3g25440, chloroplastic (LOC112193599), transcript } \\
\text { variant X2 }\end{array}$ \\
\hline Rh12GR_13539_496P & $1.62 \mathrm{E}-07$ & - & -1.24 & 0 & 0 & 2687062 & $\begin{array}{l}\text { Vitis vinifera } \mathrm{E} 3 \text { ubiquitin-protein ligase Arkadia } \\
\text { (LOC100248215) }\end{array}$ \\
\hline RhMCRND_13074_681P & $5.45 \mathrm{E}-07$ & 1.36 & 0 & - & 3 & 9613831 & $\begin{array}{l}\text { Rosa chinensis protein C2-DOMAIN ABA-RELATED 5-like } \\
\text { (LOC112192906) }\end{array}$ \\
\hline RhMCRND_9915_389Q & $5.69 \mathrm{E}-07$ & 0 & - & -1.23 & 3 & 9758183 & $\begin{array}{l}\text { Rosa chinensis glutathione S-transferase DHAR3, chloroplas- } \\
\text { tic (LOC112195020) }\end{array}$ \\
\hline Rh12GR_59259_108P & $6.19 \mathrm{E}-07$ & 2.05 & 0.89 & 0 & 3 & & $\begin{array}{l}\text { Rosa chinensis } \mathrm{BTB} / \mathrm{POZ} \text { and MATH domain containing } \\
\text { protein }\end{array}$ \\
\hline RhMCRND_9892_919P & $7.11 \mathrm{E}-07$ & - & -1.25 & 0 & 3 & 9165684 & $\begin{array}{l}\text { Rosa chinensis uncharacterized LOC112193027 } \\
\text { (LOC112193027), transcript variant X1, mRNA }\end{array}$ \\
\hline Rh12GR_12098_1092Q & $1.30 \mathrm{E}-06$ & - & -1.23 & 0 & 3 & 370111 & $\begin{array}{l}\text { Rosa chinensis uncharacterized LOC112192505, transcript } \\
\text { variant X4 }\end{array}$ \\
\hline RhK5_6755_333P & $1.33 \mathrm{E}-06$ & - & 0 & 1.16 & 3 & 11931437 & $\begin{array}{l}\text { Rosa chinensis transcription termination factor MTERF4, } \\
\text { chloroplastic (LOC112193459) }\end{array}$ \\
\hline Rh12GR_6077_815P & $1.37 \mathrm{E}-06$ & 0 & -1.18 & - & 3 & 5193454 & $\begin{array}{l}\text { Rosa chinensis probable lysophospholipase BODYGUARD } 4 \\
\text { (LOC112192624), transcript variant X1 }\end{array}$ \\
\hline RhMCRND_11099_934P & $1.50 \mathrm{E}-06$ & - & -1.15 & 0 & 3 & 9179620 & $\begin{array}{l}\text { Rosa chinensis psbP domain-containing protein 6, chloroplas- } \\
\text { tic (LOC112191588), transcript variant X1 }\end{array}$ \\
\hline Rh12GR_37799_568Q & $2.50 \mathrm{E}-06$ & 0 & -1.18 & - & 3 & 6468674 & $\begin{array}{l}\text { Rosa chinensis polyglutamine binding protein, WW domain } \\
\text { binding protein }\end{array}$ \\
\hline RhMCRND_20513_1468P & $2.51 \mathrm{E}-06$ & 0 & -1.18 & - & 3 & 5667332 & $\begin{array}{l}\text { Rosa chinensis putative pentatricopeptide repeat-containing } \\
\text { protein At5g08490 (LOC112193021), transcript variant X2 }\end{array}$ \\
\hline Rh12GR_19029_1911P & $2.60 \mathrm{E}-06$ & - & -1.20 & 0 & 0 & 25447725 & $\begin{array}{l}\text { Rosa chinensis pentatricopeptide repeat-containing protein } \\
\text { At5g15010, mitochondrial-like (LOC112192673), transcript } \\
\text { variant X1 }\end{array}$ \\
\hline Rh12GR_86832_276P & $2.67 \mathrm{E}-06$ & 0 & -1.16 & - & NA & NA & Rosa chinensis U-box_domain-containing_protein_4 \\
\hline Rh12GR_81252_184Q & $2.80 \mathrm{E}-06$ & 0 & -1.16 & - & NA & NA & $\begin{array}{l}\text { Rosa chinensis polyglutamine binding protein, WW domain } \\
\text { binding protein }\end{array}$ \\
\hline RhMCRND_2903_1233Q & $3.00 \mathrm{E}-06$ & - & 0 & -1.14 & 0 & 2544759 & $\begin{array}{l}\text { Rosa chinensis pentatricopeptide repeat-containing protein } \\
\text { At5g15010, mitochondrial-like (LOC112192673), transcript } \\
\text { variant X1 }\end{array}$ \\
\hline Rh12GR_54251_670P & $3.05 \mathrm{E}-06$ & 0 & -1.15 & - & 3 & 5665174 & $\begin{array}{l}\text { Rosa chinensis putative pentatricopeptide repeat-containing } \\
\text { protein t5g08490(LOC112193021), transcript variant X2 }\end{array}$ \\
\hline
\end{tabular}

with callus size on CIM2 and has a function in controlling developmental programs through translational regulation of auxin response factors (Rosado et al. 2012).

In addition to the markers significantly associated with callus induction on CIM1, we found a clear formation of peaks of marker clusters. In this instance, the largest number of significant SNPs and the strongest clustering of markers leads to a conspicuous broad peak of markers at the beginning of chromosome 3 . This cluster spanning a large region of more than $15 \mathrm{Mb}$ does not comprise any of the most prominent genes influencing callus induction, e.g., WOX, $A R F, C D K$ or $C Y C$ genes. However, the predicted transcripts of the reference genome of $R$. chinensis cv. Old Blush (Hibrand Saint-Oyant et al. 2018) for this region indicates that this region harbors several predicted genes with similarity to factors also known to be either directly involved in either callus formation or in related developmental processes. Examples of such genes are 


\section{Rh12GR 37799 568Q}

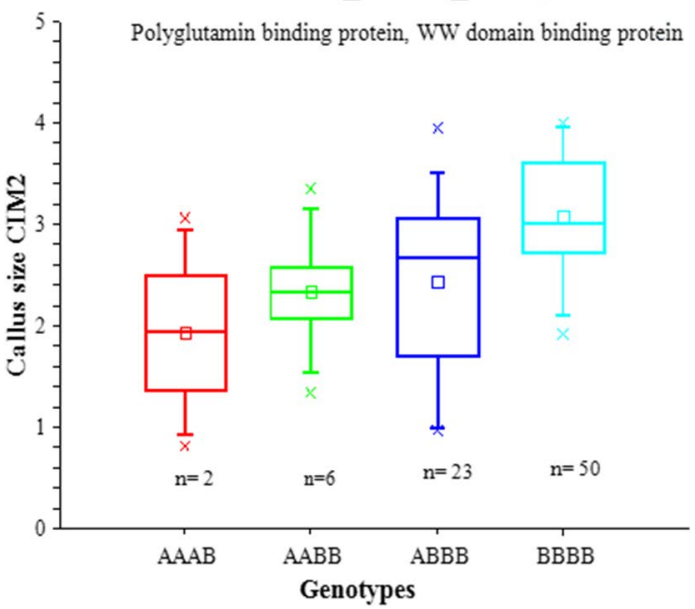

Fig. 5 Genotypic effects of SNP markers associated with callus size on CIM2, RhK5_5473_763P (Rosa chinensis S-formylglutathione hydrolase (LOC112191850), mRNA and Rh12GR_37799_568Q (Rosa chinensis polyglutamine binding protein, WW domain bind-
RhK5 $5473763 P$

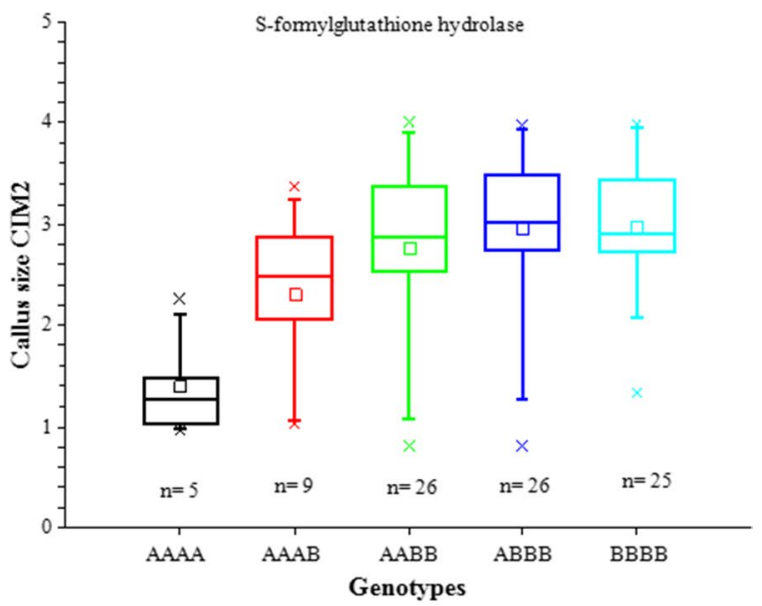

ing protein). Small square=mean; continuous line $=$ median; asterisk $=$ minimum, maximum; box $=1$ st and 3rd quartiles; and whisker $=$ standard deviation)

Table 4 Significant SNPs associated with callus size induced on CIM2

\begin{tabular}{|c|c|c|c|c|c|c|c|}
\hline \multirow[t]{2}{*}{ Marker } & \multirow[t]{2}{*}{ p-value } & \multicolumn{3}{|l|}{ Effects } & \multirow[t]{2}{*}{$\mathrm{ChR}$} & \multirow[t]{2}{*}{ Position } & \multirow[t]{2}{*}{ Gene prediction } \\
\hline & & $\mathrm{A}: \mathrm{A}$ & $\mathrm{A}: \mathrm{B}$ & $\mathrm{B}: \mathrm{B}$ & & & \\
\hline RhK5_107_2439P & $2.24 \mathrm{E}-18$ & - & 0 & 0.51 & 6 & 45395443 & $\begin{array}{l}\text { Rosa chinensis chromatin modification-related protein EAF1 } \\
\text { B-like (LOC112172241), transcript variant X2 }\end{array}$ \\
\hline RhMCRND_6130_146Q & $3.2 \mathrm{E}-12$ & - & 0.66 & 0 & 2 & 68676139 & $\begin{array}{l}\text { Rosa chinensis chorismate mutase } 1 \text {, chloroplastic } \\
\text { (LOC112188602) }\end{array}$ \\
\hline RhMCRND_10042_489P & $1.60 \mathrm{E}-09$ & 0 & - & 0.51 & 6 & 62167206 & $\begin{array}{l}\text { Rosa chinensis } 54 \text { S ribosomal protein L24, mitochondrial } \\
\quad(\text { LOC } 112174756)\end{array}$ \\
\hline RhK5_4750_1179Q & $1.26 \mathrm{E}-08$ & 1.14 & 0 & - & 3 & 7868346 & $\begin{array}{l}\text { Rosa chinensis uncharacterized CRM domain-containing } \\
\text { protein At3g25440, chloroplastic (LOC112193599), tran- } \\
\text { script variant X1 }\end{array}$ \\
\hline RhK5_12450_841P & $1.6 \mathrm{E}-07$ & 0.62 & 0.29 & 0 & 2 & 38349478 & $\begin{array}{l}\text { Rosa chinensis transmembrane E3 ubiquitin-protein ligase } 1 \\
\text { (LOC112188470), transcript variant X1 }\end{array}$ \\
\hline RhMCRND_4377_105P & $5.3 \mathrm{E}-07$ & 0 & -1.63 & -0.76 & 2 & 31990763 & Rosa chinensis aspartic proteinase Asp1 (LOC112190217) \\
\hline RhK5_5473_763P & $6.12 \mathrm{E}-07$ & 0.003 & 0 & -1.68 & 3 & 18402920 & $\begin{array}{l}\text { Rosa chinensis S-formylglutathione hydrolase } \\
\text { (LOC112191850) }\end{array}$ \\
\hline RhK5_12078_99Q & $1.00 \mathrm{E}-06$ & -1.71 & 0 & -0.10 & 3 & 17475978 & $\begin{array}{l}\text { Rosa chinensis folylpolyglutamate synthase } \\
\text { (LOC112194857), transcript variant X5 }\end{array}$ \\
\hline RhK5_6079_150Q & $2.70 \mathrm{E}-06$ & - & 1.23 & 0 & 4 & 9719228 & $\begin{array}{l}\text { Rosa chinensis protein SULFUR DEFICIENCY-INDUCED } \\
2 \text { (LOC112201022) }\end{array}$ \\
\hline Rh12GR_37799_568Q & $2.79 \mathrm{E}-06$ & - & -0.79 & 0 & 3 & 6468674 & $\begin{array}{l}\text { Rosa chinensis polyglutamine binding protein, WW domain } \\
\text { binding protein }\end{array}$ \\
\hline Rh12GR_3363_1266Q & $3.20 \mathrm{E}-06$ & - & 0 & 0.78 & 3 & 13761410 & Rosa chinensis pectinesterase-like (LOC112191366) \\
\hline
\end{tabular}

LOB (LATERAL ORGAN BOUNDARIES) domain-containing factors at the position of $6 \mathrm{Mb}$, a DELLA GAIlike transcriptional regulator that acts as a repressor of the cytokinin pathway (Ito et al. 2018), a PLATZ (PLANT A/T RICH SEQUENCE AND ZINC BINDING PROTEIN) family transcriptional repressor involved in the regulation of cell division (Kim et al. 2018), a regulatory protein of the TORI (TARGET OF RAPAMYCIN) type putatively modulating plant cell growth (Steiner et al. 2016), and RSI-1 (REDUCED SYSTEMIC IMMUNITY), a molecular marker for auxin-induced lateral root initiation (Taylor and Scheuring 1994), as well as several LRR-receptor-like protein kinases and transcription factors. The relatively wide extension of this peak region on chromosome 3 might also 
indicate the presence of more than one causal factor for callus induction.

At the second less defined peak at the end of chromosome 3 , which does not reach the significance level, genes with similarity to BABYBOOM (BBMI and BBM2) involved in embryogenic callus formation (Ikeuchi et al. 2013; Yang et al. 2014; Du et al. 2019) are located at a position of approximately $46 \mathrm{Mb}$. More pronounced peaks were detected on chromosomes 0 , two and five. Chromosome 0 comprises all sequences that could not be assigned unequivocally to a genomic position among the seven rose chromosomes. The first analysis indicates that Rcr0 comprises sequences from several chromosomes, including larger groups of contigs that might belong to chromosomes four and two, making it impossible to locate these sequences exactly (Hibrand Saint-Oyant et al. 2018). However, the clearly defined peak reaches the significance threshold and therefore comprises genetic factors with a strong influence on callus formation on CIM1. The two peaks on chromosome 2 comprise regions in which $C D K$, homologs of $P A S$ genes and further $L B D$ genes are located (Fig. 3a; Table 3), all of which are candidate genes that influence callus formation. Taken together, the data for callus induction on CIM1 indicate a major QTL on chromosome 3, as well as several minor QTLs on other chromosomes, including chromosomes 2, 3 and 5. The influence of other factors apart from the major QTL on chromosome 3 is also supported by the limited effect of markers derived from the region on chr. 3, indicating that despite the highly significant effect, they explain only part of the whole phenotypic variation.

In contrast to callus induction on CIM1, the induction on CIM2 containing the strong auxin 2,4-D did not lead to marker associations as clear as for CIM1. However, one region on chromosome 3 identical to the major QTL for callus induction on CIM1 is significant, and the minor regions on chromosome 2 also show some small peaks matching those for CIM1. In addition, a region in the lower region of chromosome 4 , as well as on chromosome 6 , shows minor peaks with individual significant markers. This finding indicates a tendency similar to callus induction on CIM1 with an overall smaller marker-trait association and further supports the hypothesis of common genetic factors discussed above for the correlation of both traits. The smaller effects of genomic regions on callus formation on CIM2 may be observed because more genes contribute to the phenotypic variation among the 96 plants tested. Other possible reasons are differences in the phenotypic variation between callus induction on CIM1 and CIM2 (Fig. 2): callus induction on CIM2 was more effective than on CIM1 in that all plants showed some degree of callus formation, and the average rates of callus induction were considerably higher on CIM2 than on CIM1 (Fig. 2), leading to a lower degree of differentiation among the analyzed genotypes. One can speculate that an earlier time point for phenotyping callus development on CIM2 might have detected a stronger differentiation between genotypes and therefore would have uncovered stronger genetic effects at earlier time points than the time point actually used. Furthermore, we used only 96 genotypes for our GWAS analysis, which only enables the detection of QTLs with strong effects. Larger plant populations might reveal additional QTLs with smaller effects. For example, in wheat, QTLs for callus induction were identified on chromosomes 1D, 5A, and 6D (Ma et al. 2016) and on chromosomes B2 and D2 in soybean (Yang et al. 2011). In the Populus genome, eight loci were distributed across chromosomes III, IV, XI, VIII, IX, XII, XV and XVII (Tuskan et al. 2018). In rice, 21 significant loci located in rice callus induction QTLs were revealed (Zhang et al. 2019). Given the relatively small resolution, our GWAS population provided SNPs with significant association to the traits under study that might only be linked to the causal factors. These might not show up as an associated marker because the criteria for the design of the WagRhSNP chip were highly stringent, excluding many transcribed genes from marker design (Koning-Boucoiran et al. 2015). Therefore, further functional analyses are needed to identify the genes that led to the observed associations. Apart from analyzing larger plant populations, these studies might comprise the quantification of gene expression or in-depth sequence comparison for genotypes with contrasting capacity for callus formation, as well as transgenic experiments with either knockdown/ knockout or overexpression of individual candidate genes and subsequent quantification of callus formation in vitro. However, the extent of such experiments was beyond the scope of the current study and they need to be addressed in subsequent investigations.

\section{Conclusions}

In the present study, we showed that callus induction in roses is strongly dependent on both the genotype and the medium used. Though measurement of in vitro traits in large populations is extremely laborious, GWAS studies have the potential to unravel major genetic factors acting on those traits. By GWAS, we identified some genomic regions harboring factors with a strong genetic effect on callus formation with a major QTL located on chromosome 3. Among these SNPs, for callus size on medium CIM1 the SNPs Rh12GR_12098_1092Q (uncharacterized gene) and RhMCRND_2903_1233Q in a gene encoding a pentatricopeptide repeat-containing protein had large effects of 2.7 and 1.8, respectively. Furthermore, two SNPs, RhK5_5473_763P (S-formylglutathione hydrolase) and Rh12GR_37799_568Q (polyglutamine binding protein, $\mathrm{WW}$ domain binding 
protein), were associated with callus size on CIM2 with large effect sizes (1.2 and 1.6, respectively). These markers with a strong association with callus formation can serve as a starting point for both the identification of genotypes with a strongly contrasting capacity for callus induction, which is useful for further studies on callus induction in roses, and for the identification of genes with effects on callus induction in roses, therefore extending our knowledge on developmental processes in this important woody ornamental.

Acknowledgements Open Access funding provided by Projekt DEAL. This study was carried out with financial support from the Vietnamese Government and the Department of Molecular Plant Breeding, Institute of Plant Genetics, Leibniz Universität Hannover, Hannover, Germany.

Author contributions NTHN conducted the experiments, completed the statistical and data analysis and wrote most of the manuscript. TW contributed to the experimental setup and wrote part of the manuscript. TD was involved in planning the experiments and wrote parts of the manuscript. All authors read and approved the manuscript.

Funding NTHN received a stipend from the Vietnamese Government.

Availability of data and material Data and material not provided in this publication or previously published are available on request to the corresponding author.

\section{Compliance with ethical standards}

Conflict of interest The authors declare no conflicts of interest.

Informed consent All authors declare their consent for this publication.

Open Access This article is licensed under a Creative Commons Attribution 4.0 International License, which permits use, sharing, adaptation, distribution and reproduction in any medium or format, as long as you give appropriate credit to the original author(s) and the source, provide a link to the Creative Commons licence, and indicate if changes were made. The images or other third party material in this article are included in the article's Creative Commons licence, unless indicated otherwise in a credit line to the material. If material is not included in the article's Creative Commons licence and your intended use is not permitted by statutory regulation or exceeds the permitted use, you will need to obtain permission directly from the copyright holder. To view a copy of this licence, visit http://creativecommons.org/licenses/by/4.0/.

\section{References}

Aki S, Nakai H, Aoyama T, Oka A, Tsuge T (2011) AtSAP130/ AtSF3b-3 function is required for reproduction in Arabidopsis thaliana. Plant Cell Physiol 52:1330-1339. https://doi. org/10.1093/pcp/pcr077

Auger A, Galarneau L, Altaf M, Nourani A, Doyon Y, Utley RT, Cronier D, Allard S, Cote J (2008) EAF1 is the platform for NuA4 molecular assembly that evolutionarily links chromatin acetylation to ATP-dependent exchange of histone $\mathrm{H} 2 \mathrm{~A}$ variants. Mol Cell Biol 28:2257-2270. https://doi.org/10.1128/MCB.01755-07
Bello OA, Fajimi O, Esan EB, Obembe OO (2018) Callus and etiolation induction data from explants of Solanecio biafrae (Olive \& Hierne) C. Jeffrey cultured in the dark. Data Brief 20:113-117. https://doi.org/10.1016/j.dib.2018.07.029

Bendahmane M, Dubois A, Raymond O, Le Bris M (2013) Genetics and genomics of flower initiation and development in roses. J Exp Bot 64:847-857. https://doi.org/10.1093/jxb/ers387

Bieluszewski T, Galganski L, Sura W, Bieluszewska A, Abram M, Ludwikow A, Ziolkowski P, Sadowski J (2015) AtEAF1 is a potential platform protein for Arabidopsis NuA4 acetyltransferase complex. BMC Plant Biol 15:75. https://doi.org/10.1186/s1287 0-015-0461-1

Bradbury PJ, Zhang Z, Kroon DE, Casstevens TM, Ramdoss Y, Buckler ES (2007) TASSEL: software for association mapping of complex traits in diverse samples. Bioinformatics 23:2633-2635. https ://doi.org/10.1093/bioinformatics/btm308

Canli FA (2003) Effects of dark and TDZ on callus formation of rose leaf explants. Pakistan J Biol Sci 6:1672-1674. https://doi. org/10.3923/pjbs.2003.1672.1674

Che P, Lall S, Nettleton D, Howell SH (2006) Gene expression programs during shoot, root, and callus development in Arabidopsis tissue culture. Plant Physiol 141:620-637. https://doi.org/10.1104/ pp. 106.081240

Chen H, Gu X-H, Zhou Y, Ge Z, Wang B, Siok WT, Wang G, Huen M, Jiang Y, Tan L-H, Sun Y (2017) A genome-wide association study identifies genetic variants associated with mathematics ability. Sci Rep 7:40365. https://doi.org/10.1038/srep40365

Cheng Y, Liu H, Cao L, Wang S, Li Y, Zhang Y, Jiang W, Zhou Y, Wang H (2015) Down-regulation of multiple CDK inhibitor ICK/KRP genes promotes cell proliferation, callus induction and plant regeneration in Arabidopsis. Front Plant Sci 6:825. https://doi.org/10.3389/fpls.2015.00825

Dale PJ, Deambrogio E (1979) A comparison of callus induction and plant regeneration from different explants of Hordeum vulgare. Z Pflanzenphysiol 94:65-77. https://doi.org/10.1016/S0044 $-328 X(79) 80249-4$

Disch S, Anastasiou E, Sharma VK, Laux T, Fletcher JC, Lenhard M (2006) The E3 ubiquitin ligase BIG BROTHER controls Arabidopsis organ size in a dosage-dependent manner. Curr Biol 16:272-279. https://doi.org/10.1016/j.cub.2005.12.026

Dohm A, Ludwig C, Nehring K, Debener T (2001) Somatic embryogenesis in roses. Acta Hortic 547:341-347. https://doi. org/10.17660/ActaHortic.2001.547.40

Du X, Fang T, Liu Y, Huang L, Zang M, Wang G, Liu Y, Fu J (2019) Transcriptome profiling predicts new genes to promote maize callus formation and transformation. Front Plant Sci 10:1633. https://doi.org/10.3389/fpls.2019.01633

Gershater MC, Edwards R (2007) Regulating biological activity in plants with carboxylesterases. Plant Sci 173:579-588. https:// doi.org/10.1016/j.plantsci.2007.08.008

Fan M, Xu C, Xu K, Hu Y (2012) LATERAL ORGAN BOUNDARIES DOMAIN transcription factors direct callus formation in Arabidopsis regeneration. Cell Res 22:1169-1180. https://doi. org/10.1038/cr.2012.63

Hall TA (1999) BioEdit: a user-friendly biological sequence alignment editor and analysis program for Windows 95/98/NT:95-98

Hardy OJ, Vekemans X (2002) Spagedi: a versatile computer program to analyse spatial genetic structure at the individual or population levels. Mol Ecol Notes 2:618-620. https://doi.org/1 0.1046/j.1471-8286.2002.00305.x

Harrar Y, Bellec Y, Bellini C, Faure J-D (2003) Hormonal control of cell proliferation requires PASTICCINO genes. Plant Physiol 132:1217-1227. https://doi.org/10.1104/pp.102.019026

Hibrand Saint-Oyant L, Ruttink T, Hamama L, Kirov I, Lakhwani D, Zhou NN, Bourke PM, Daccord N, Leus L, Schulz D, Van de Geest H, Hesselink T, Van Laere K, Debray K, Balzergue S, 
Thouroude T, Chastellier A, Jeauffre J, Voisine L, Gaillard S, Borm TJA, Arens P, Voorrips RE, Maliepaard C, Neu E, Linde M, Le Paslier MC, Bérard A, Bounon R, Clotault J, Choisne N, Quesneville H, Kawamura K, Aubourg S, Sakr S, Smulders MJM, Schijlen E, Bucher E, Debener T, De Riek J, Foucher F (2018) A high-quality genome sequence of Rosa chinensis to elucidate ornamental traits. Nature Plants 4(7):473-484

Ho S-R, Lee Y-J, Lin W-C (2015) Regulation of RNF144A E3 ubiquitin ligase activity by self-association through its transmembrane domain. J Biol Chem 290:23026-23038. https://doi.org/10.1074/ jbc.M115.645499

Hsia C-n, Korban SS (1996) Organogenesis and somatic embryogenesis in callus cultures of Rosa hybrida and Rosa chinensis minima. Plant Cell Tissue Organ Culture 44:1-6

Huang X, Liu J, Feng H, Ma Y, Zhang L, Han H (2018) Effects of different plant hormones on callus induction and plant regeneration of miniature roses (Rosa hybrida L.). HIJ. https://doi. org/10.15406/hij.2018.02.00053

Hubisz MJ, Falush D, Stephens M, Pritchard JK (2009) Inferring weak population structure with the assistance of sample group information. Mol Ecol Resour 9:1322-1332. https://doi.org/10.111 1/j.1755-0998.2009.02591.x

Ikeuchi M, Sugimoto K, Iwase A (2013) Plant callus: mechanisms of induction and repression. Plant Cell 25:3159-3173. https://doi. org/10.1105/tpc.113.116053

Ikeuchi M, Iwase A, Rymen B, Lambolez A, Kojima M, Takebayashi Y, Heyman J, Watanabe S, Seo M, Veylder L de, Sakakibara $\mathrm{H}$, Sugimoto K (2017) Wounding triggers callus formation via dynamic hormonal and transcriptional changes. Plant Physiol 175:1158-1174. https://doi.org/10.1104/pp.17.01035

Inzé D, Veylder L de (2006) Cell cycle regulation in plant development. Annu Rev Genet 40:77-105. https://doi.org/10.1146/annur ev.genet.40.110405.090431

Ito T, Okada K, Fukazawa J, Takahashi Y (2018) DELLA-dependent and -independent gibberellin signaling. Plant Signal Behav 13:e1445933. https://doi.org/10.1080/15592324.2018.1445933

Iwase A, Mitsuda N, Koyama T, Hiratsu K, Kojima M, Arai T, Inoue Y, Seki M, Sakakibara H, Sugimoto K, Ohme-Takagi M (2011) The AP2/ERF transcription factor WIND1 controls cell dedifferentiation in Arabidopsis. Curr Biol 21:508-514. https://doi. org/10.1016/j.cub.2011.02.020

Iwase A, Harashima H, Ikeuchi M, Rymen B, Ohnuma M, Komaki S, Morohashi K, Kurata T, Nakata M, Ohme-Takagi M, Grotewold E, Sugimoto K (2017) WIND1 promotes shoot regeneration through transcriptional activation of ENHANCER OF SHOOT REGENERATION1 in Arabidopsis. Plant Cell 29:54-69. https ://doi.org/10.1105/tpc.16.00623

Jayanthi M, Susanthi B, Murali Mohan N, Mandal PK (2015) In vitro somatic embryogenesis and plantlet regeneration from immature male inflorescence of adult dura and tenera palms of Elaeis guineensis (Jacq.). Springerplus 4:256. https://doi.org/10.1186/ s40064-015-1025-4

Kareem A, Durgaprasad K, Sugimoto K, Du Y, Pulianmackal AJ, Trivedi ZB, Abhayadev PV, Pinon V, Meyerowitz EM, Scheres B, Prasad K (2015) PLETHORA genes control regeneration by a two-step mechanism. Curr Biol 25:1017-1030. https://doi. org/10.1016/j.cub.2015.02.022

Khosh-Khui M, Sink KC (1982) Callus induction and culture of Rosa. Sci Hortic 17:361-370. https://doi.org/10.1016/03044238(82)90117-0

Kim JH, Kim J, Jun SE, Park S, Timilsina R, Kwon DS, Kim Y, Park S-J, Hwang JY, Nam HG, Kim G-T, Woo HR (2018) ORESARA15, a PLATZ transcription factor, mediates leaf growth and senescence in Arabidopsis. New Phytol 220:609-623. https://doi. org/10.1111/nph.15291
Kirov I, van Laere K, Riek J de, Keyser E de, van Roy N, Khrustaleva L (2014) Anchoring linkage groups of the Rosa genetic map to physical chromosomes with tyramide-FISH and EST-SNP markers. PLoS ONE 9:e95793. https://doi.org/10.1371/journ al.pone. 0095793

Koning-Boucoiran CFS, Esselink GD, Vukosavljev M, van 't Westende WPC, Gitonga VW, Krens FA, Voorrips RE, van de Weg WE, Schulz D, Debener T, Maliepaard C, Arens P, Smulders MJM (2015) Using RNA-Seq to assemble a rose transcriptome with more than 13,000 full-length expressed genes and to develop the WagRhSNP 68 k Axiom SNP array for rose (Rosa L.). Front Plant Sci 6:1-10. https://doi.org/10.3389/fpls.2015.00249

Koo AJK, Gao X, Jones AD, Howe GA (2009) A rapid wound signal activates the systemic synthesis of bioactive jasmonates in Arabidopsis. Plant J 59:974-986. https://doi.org/10.1111/j.1365313X.2009.03924.X

Kordic S, Cummins I, Edwards R (2002) Cloning and characterization of an S-formylglutathione hydrolase from Arabidopsis thaliana. Arch Biochem Biophys 399:232-238. https://doi.org/10.1006/ abbi.2002.2772

Kumlay AM, Ercisli S (2015) Callus induction, shoot proliferation and root regeneration of potato (Solanum tuberosum L.) stem node and leaf explants under long-day conditions. Biotechnol Biotechnol Equip 29:1075-1084. https://doi.org/10.1080/13102 818.2015.1077685

Kuusiene S, Kandzezauskaite M (2001) The influence of genotype and explant for callus induction and proliferation of Rosa floribunda. Acta Hortic. https://doi.org/10.17660/ActaHortic.2001.560.101

Lee K, Park O-S, Seo PJ (2017) Arabidopsis ATXR2 deposits $\mathrm{H} 3 \mathrm{~K} 36 \mathrm{me} 3$ at the promoters of LBD genes to facilitate cellular dedifferentiation. Sci Signal. https://doi.org/10.1126/scisignal. aan0316

Leus L, van Laere K, Riek J, van Huylenbroeck J (2018) Rose. In: van Huylenbroeck J (ed) Ornamental crops. Springer, Berlin, pp 719-767

Ma J, Deng M, Lv S-Y, Yang Q, Jiang Q-T, Qi P-F, Li W, Chen G-Y, Lan X-J, Wei Y-M (2016) Identification of QTLs associated with tissue culture response of mature wheat embryos. Springerplus 5:1552. https://doi.org/10.1186/s40064-016-3241-y

Ma L, Liu M, Yan Y, Qing C, Zhang X, Zhang Y, Long Y, Wang L, Pan L, Zou C, Li Z, Wang Y, Peng H, Pan G, Jiang Z, Shen Y (2018) Genetic dissection of maize embryonic callus regenerative capacity using multi-locus genome-wide association studies. Front Plant Sci 9:561. https://doi.org/10.3389/fpls.2018.00561

Marchant R, Davey MR, Lucas JA, Power JB (1996) Somatic embryogenesis and plant regeneration in Floribunda rose (Rosa hybrida L.) cvs. trumpeter and glad tidings. Plant Sci 120:95-105. https ://doi.org/10.1016/S0168-9452(96)04479-2

Murashige T, Skoog F (1962) A revised medium for rapid growth and bio assays with tobacco tissue cultures. Physiol Plant 15:473-497. https://doi.org/10.1111/j.1399-3054.1962.tb08052.x

Nguyen THN, Schulz D, Winkelmann T, Debener T (2017) Genetic dissection of adventitious shoot regeneration in roses by employing genome-wide association studies. Plant Cell Rep 36:14931505. https://doi.org/10.1007/s00299-017-2170-8

Nguyen THN, Tänzer S, Rudeck J, Winkelmann T, Debener T (2020) Genetic analysis of adventitious root formation in vivo and in vitro in a diversity panel of roses. Sci Hortic 266:109277. https://doi. org/10.1016/j.scienta.2020.109277

Noriega C, Söndahl MR (1991) Somatic embryogenesis in hybrid tea roses. Nat Biotechnol 9:991-993. https://doi.org/10.1038/nbt10 91-991

Okushima Y, Fukaki H, Onoda M, Theologis A, Tasaka M (2007) ARF7 and ARF19 regulate lateral root formation via direct activation of LBD/ASL genes in Arabidopsis. Plant Cell 19:118-130. https://doi.org/10.1105/tpc.106.047761 
Osman NI, Awal A, Sidik NJ, Abdullah S (2013) Callus induction and somaticembryogenesis from leaf and nodal explants of Lycium barbarum L. (Goji). Biotechnology 12:36-45. https:// doi.org/10.3923/biotech.2013.36.45

Pati PK, Kaur N, Sharma M, Ahuja PS (2010) In vitro propagation of rose. Methods Mol Biol 589:163-176. https://doi. org/10.1007/978-1-60327-114-1_16

Pfeffer S, Woellhaf MW, Herrmann JM, Förster F (2015) Organization of the mitochondrial translation machinery studied in situ by cryoelectron tomography. Nat Commun 6:6019. https://doi. org/10.1038/ncomms7019

Prange ANS, Bartsch M, Serek M, Winkelmann T (2010) Regeneration of different Cyclamen species via somatic embryogenesis from callus, suspension cultures and protoplasts. Sci Hortic 125:442450. https://doi.org/10.1016/j.scienta.2010.04.018

Rosado A, Li R, van de Ven W, Hsu E, Raikhel NV (2012) Arabidopsis ribosomal proteins control developmental programs through translational regulation of auxin response factors. Proc Natl Acad Sci USA 109:19537-19544. https://doi.org/10.1073/pnas.1214774109

Schulz DF, Schott RT, Voorrips RE, Smulders MJM, Linde M, Debener $\mathrm{T}$ (2016) Genome-wide association analysis of the anthocyanin and carotenoid contents of rose petals. Front Plant Sci 7:1798. https://doi.org/10.3389/fpls.2016.01798

Sena G, Wang X, Liu H-Y, Hofhuis H, Birnbaum KD (2009) Organ regeneration does not require a functional stem cell niche in plants. Nature 457:1150-1153. https://doi.org/10.1038/natur e07597

Shamsiah A, Awal A, Nurathrah S, Khairul-Azmir M, Norrizah JS (2011) Effect of BAP concentration on in vitro shoot multiplication and callus induction of Jatropha curcas. Acta Hortic. https ://doi.org/10.17660/ActaHortic.2011.923.30

Shang B, Xu C, Zhang X, Cao H, Xin W, Hu Y (2016) Very-long-chain fatty acids restrict regeneration capacity by confining pericycle competence for callus formation in Arabidopsis. Proc Natl Acad Sci USA 113:5101-5106. https://doi.org/10.1073/pnas.15224 66113

Shin J, Seo PJ (2018) Varying auxin levels induce distinct pluripotent states in callus cells. Front Plant Sci 9:1653. https://doi. org/10.3389/fpls.2018.01653

Staiger D, Brown JWS (2013) Alternative splicing at the intersection of biological timing, development, and stress responses. Plant Cell 25:3640-3656. https://doi.org/10.1105/tpc.113.113803

Steiner E, Livne S, Kobinson-Katz T, Tal L, Pri-Tal O, Mosquna A, Tarkowská D, Mueller B, Tarkowski P, Weiss D (2016) The putative O-linked $\mathrm{N}$-acetylglucosamine transferase SPINDLY inhibits class I TCP proteolysis to promote sensitivity to cytokinin. Plant Physiol 171:1485-1494. https://doi.org/10.1104/pp.16.00343

Sugimoto K, Jiao Y, Meyerowitz EM (2010) Arabidopsis regeneration from multiple tissues occurs via a root development pathway. Dev Cell 18:463-471. https://doi.org/10.1016/j.devcel.2010.02.004
Taimori N, Kahrizi D, Abdossi V, Papzan AH (2016) Cell dedifferentiation, callus induction and somatic embryogenesis in Crataegus spp. Cell Mol Biol (Noisy-le-grand) 62:100-107

Taylor BH, Scheuring CF (1994) A molecular marker for lateral root initiation: the RSI-1 gene of tomato (Lycopersicon esculentum Mill) is activated in early lateral root primordia. Mol Gen Genet 243:148-157. https://doi.org/10.1007/BF00280311

Tuskan GA, Mewalal R, Gunter LE, Palla KJ, Carter K, Jacobson DA, Jones PC, Garcia BJ, Weighill DA, Hyatt PD, Yang Y, Zhang J, Reis N, Chen J-G, Muchero W (2018) Defining the genetic components of callus formation: a GWAS approach. PLoS ONE 13:e0202519. https://doi.org/10.1371/journal.pone.0202519

Voorrips RE, Gort G, Vosman B (2011) Genotype calling in tetraploid species from bi-allelic marker data using mixture models. BMC Bioinformatics 12:172. https://doi.org/10.1186/1471-2105-12-172

Xu C, Cao H, Zhang Q, Wang H, Xin W, Xu E, Zhang S, Yu R, Yu $\mathrm{D}, \mathrm{Hu}$ Y (2018) Control of auxin-induced callus formation by bZIP59-LBD complex in Arabidopsis regeneration. Nat Plants 4:108-115. https://doi.org/10.1038/s41477-017-0095-4

Yang C, Zhao T, Yu D, Gai J (2011) Mapping QTLs for tissue culture response in soybean (Glycine max (L.) Merr.). Mol Cells 32:337342. https://doi.org/10.1007/s10059-011-0063-1

Yang HF, Kou YP, Gao B, Soliman TMA, Xu KD, Ma N, Cao X, Zhao LJ (2014) Identification and functional analysis of BABY BOOM genes from Rosa canina. Biol Plant 58:427-435. https:// doi.org/10.1007/s10535-014-0420-y

Yuan J-L, Yue J-J, Wu X-L, Gu X-P (2013) Protocol for callus induction and somatic embryogenesis in Moso Bamboo. PLoS ONE 8:e81954. https://doi.org/10.1371/journal.pone.0081954

Yunista, Hapsoro DWI (2011) In vitro callus induction and embryogenesis of oil palm (Elaeis guineensis Jacq.) from leaf explants. HAYATI J Biosci 18:61-65. https://doi.org/10.4308/hjb.18.2.61

Zakizadeh H, Debener T, Sriskandarajah S, Frello S, Serek M (2010) Somatic embryogenesis in miniature potted rose (Rosa hybrida L). Acta Hortic. https://doi.org/10.17660/ActaHortic.2010.870.30

Zhang Z, Zhao H, Li W, Wu J, Zhou Z, Zhou F, Chen H, Lin Y (2019) Genome-wide association study of callus induction variation to explore the callus formation mechanism of rice. J Integr Plant Biol 61:1134-1150. https://doi.org/10.1111/jipb.12759

Publisher's Note Springer Nature remains neutral with regard to jurisdictional claims in published maps and institutional affiliations. 